\title{
Correction to: Semivariogram and Semimadogram functions as descriptors for AMD diagnosis on SD-OCT topographic maps using Support Vector Machine
}

\author{
Alex M. Santos ${ }^{1,2^{*}}$, Anselmo C. Paiva' ${ }^{1}$, Adriana P. M. Santos ${ }^{1}$, Steve A. T. Mpinda ${ }^{3}$, Daniel L. Gomes Jr. ${ }^{1}$, \\ Aristófanes C. Silva', Geraldo Braz Jr. ', João Dallyson S. de Almeida' ${ }^{1}$ and Marcelo Gattas ${ }^{4}$
}

${ }^{*}$ Correspondence: alex.martins@ifma.edu.br ${ }^{2}$ Instituto Federal de Educação, Ciência e Tecnologia do Maranhão, São José de Ribamar, MA, Brazil Full list of author information is available at the end of the article

\section{Correction to: BioMed Eng OnLine (2018) 17:160 https://doi.org/10.1186/s12938-018-0592-3}

After publication, it was highlighted that the original publication [1] contained a spelling mistake in the first name of Marcelo Gattas. This was incorrectly captured as Marelo Gattass in the original article which has since been updated.

\section{Author details}

${ }^{1}$ Federal University of Maranhão UFMA, Applied Computing Group - NCA, Av. dos Portuqueses, SN, Campus do Bacanga, Bacanga, São Luís, MA 65085-580, Brazil. ${ }^{2}$ Instituto Federal de Educação, Ciência e Tecnologia do Maranhão, São José de Ribamar, MA, Brazil. ${ }^{3}$ Université du Québec à Montréal, Montréal, Canada. ${ }^{4}$ Pontifical Catholic University of Rio de Janeiro PUC-Rio, R. São Vicente, 225 Gávea, Rio de Janeiro, RJ 22453-900, Brazil.

The original article can be found online at https://doi.org/10.1186/s12938-018-0592-3.

\section{Publisher's Note}

Springer Nature remains neutral with regard to jurisdictional claims in published maps and institutional affiliations.

Received: 29 October 2018 Accepted: 29 October 2018

Published online: 08 November 2018

Reference

1. Santos AM, Paiva AC, Santos APM, Mpinda SAT, Gomes DL Jr, Silva AC, Braz G Jr, de Almeida JDS, Gattas M. Semivariogram and Semimadogram functions as descriptors for AMD diagnosis on SD-OCT topographic maps using Support Vector Machine. BioMed Eng OnLine. 2018;17:160. https://doi.org/10.1186/s12938-018-0592-3. 